\title{
Konsep Nomophobia pada Remaja Generasi Z
}

\author{
Indah Permata Sari ${ }^{1}$, Ifdil Ifdil ${ }^{1 *}$, Frischa Meivilona Yendi ${ }^{1}$ \\ ${ }^{123}$ Universitas Negeri Padang \\ *Corresponding author, e-mail: ifdil@konselor.org
}

\begin{abstract}
Abstrak
Perkembangan teknologi menghasilkan perangkat teknologi baru yang dapat memfasilitasi aktivitas manusia atau lebih di kenal mobile phone. Dengan kelebihan dari mobile phone atau smartphone membuat penggunanya menjadi cemas atau takut apabila tidak dapat mengakses ponselnya tersebut atau dikenal dengan istilah nomophobia. Nomophobia cenderung terjadi pada remaja generasi Z dikarenakan mereka hidup di era digital dengan perkembangan teknologi yang berkembang pesat. Teknologi sudah menjadi bagian dari hidup mereka. Apapun yang dilakukan kebanyakan berhubungan dengan dunia maya, sehingga mereka terlalu asyik dengan perangkat ponsel atau smartphonenya.
\end{abstract}

Kata Kunci: Nomophobia, remaja generasi Z.

\section{PENDAHULUAN}

Seiring berkembangnya zaman, terjadinya perkembangan dibeberapa sektor salah satunya yaitu di bidang teknologi informasi dan komunikasi. Perkembangan teknologi informasi dan komunikasi yang sangat pesat dan efek yang ditimbulkan sangat bisa dirasakan oleh setiap penduduk di dunia ini yakni dengan banyaknya perangkat-perangkat berteknologi tinggi dalam kehidupan kerja maupun dalam kehidupan sehari- hari. Salah satu hasil teknologi yang berkembang pesat adalah mobile phone. Mobile phone dikenal sebagai telepon seluler atau telepon genggam yang dapat memudahkan manusia melakukan interaksi. Tujuan Mobile phone adalah sebagai media untuk berinteraksi namun terhambat oleh jarak, namun kini telah beralih fungsi tidak hanya digunakan untuk alat berkomunikasi saja tetapi lebih dari itu, kemajuan teknoloni telah melahirkan mobile phone terbaru yang memiliki multifungsi atau dikenal smartphone (Dasiroh, Miswatun, Ilahi, \& Nurjanannah, n.d.).

Hermawati (2013) menyatakan bahwa smartphone adalah suatu perangkat yang memiliki kemampuan untuk membantu dalam berkomunikasi yang juga memiliki kemampuan seperti komputer. Pada mulanya smartphone lebih difokuskan pada alat komunikasi, namun semenjak kemajuan zaman alat ini dipercanggih dengan berbagai fitu-fitur yang ada didalamnya sehingga pengguna bisa melakukan berbagai kegiatan dengan gadget ini, mula dari bertelepon, berkirim pesan, email, berfoto, game dan sebagainya. 
Generasi Z lahir dan di besarkan di era digital dimana internet telah berkembang pesat, sejak kecil mereka sudah akrab dengan teknologi dan gadget canggih salah satunya smartphone. Generasi Z adalah mereka yang lahir setelah 1995 sampai 2010, yang artinya kini mereka berada dalam tahap perkembangan remaja. Bagi generasi $\mathrm{Z}$ informasi dan teknologi adalah hal yang sudah menjadi bagian dari kehidupan mereka. Generasi $\mathrm{Z}$ mampu mengaplikasikan semua kegiatan dalam satu waktu (multi tasking) seperti: menjalankan sosial media menggunakan ponsel, browsing menggunakan PC, dan mendengarkan musik menggunakan headset. Apapun yang dilakukan kebanyakan berhubungan dengan dunia maya, sehingga mereka terlalu asyik dengan perangkat gadgetnya atau smartphonenya. Kemudahan dan kenyamanan yang ditawarkan pada smartphone, dapat menjadi masalah apabila digunakan secara berlebihan salah satunya adalah nomophobia.

Kecanduan pada smartphone yang dialami individu dikarenakan kehadiran smartphone saat ini menjadi alat yang siap membantu segala kebutuhan manusia kapan saja dan dimana saja, seperti berkomunikasi, mencari informasi, hingga hiburan. Namun hal tersebut dapat membuat individu menjadi menggantungkan segala kebutuhannya pada smartphone. Kebiasaan mengecek smartphone terlalu sering dapat mengakibatkan seseorang mengidap nomophobia.

Nomophobia merupakan perasaan ketergantungan kepada telepon genggam atau smartphone dan mengakibatkan ketakutan berlebihan bila tidak berada disekitar atau memegangnya (Hanika, 2015). Rasa takut akibat nomophobia mengacu pada ketidaknyamanan, kegelisahan, gugup atau kesedihan yang disebabkan karena tidak terhubung dengan telepon genggam atau smartphone (T. R. P. Lestari, 2017; Mudrikah, 2019; Prasetyo, 2017). Ada beberapa faktor penyebab nomophobia yaitu jenis kelamin, harga diri, usia, extraversi dan neurotisme (Yildirim, 2014). Lebih lanjut (Yildirim, 2014) menyebutkan aspek nomophobia yaitu perasaan tidak bisa berkomunikasi, kehilangan konektivitas, tidak mampu mengakses informasi, menyerah pada kenyamanan.

\section{NOMOPHOBIA}

Istilah Nomophobia adalah singkatan untuk no-mobile-phone-phobia (Dasiroh et al., n.d.; Hafni, 2019; Latief, n.d.; T. Lestari, 2019; Mawardi, 2018) dan pertama kali diciptakan selama penelitian yang dilakukan pada tahun 2008 oleh Kantor Pos Inggis untuk menyelediki kecemasan pengguna mobile phone (T. R. P. Lestari, 2017; SecurEnvoy, 2012). Nomophobia merupakan perasaan cemas atau tidak nyaman yang timbul akibat jauh dari telepon genggam atau smartphone. Senada dengan itu (King et al., 2014) menyatakan Nomophobia merupakan ketakutan yang terjadi karena tidak ada kontak askes terhadap ponselnya.

Lebih lanjut (Yildirim, 2014) mengemukakan bahwa nomophobia merupakan rasa takut berada di luar kontak ponsel dan dianggap sebagai fobia modern akibat efek samping dari interaksi antara manusia, teknologi informasi dan komunikasi khususnya telepon genggam atau smartphone. Rasa takut akibat nomophobia mengacu pada ketidaknyamanan, kegelisahan, gugup atau kesedihan yang disebabkan karena tidak terhubung dengan telepon genggam atau smartphone (T. R. P. Lestari, 2017; Mudrikah, 2019; Prasetyo, 2017)

Berdasarkan berbagai definisi yang dikemukakan di atas, maka dapat diambil kesimpulan bahwa nomophobia berasal dari istilah no-mobile-phone-phobia yang merupakan rasa cemas atau ketakutan akibat tidak terhubung dengan telepon genggam atau smartphonenya yang disebabkan oleh beberapa kondisi seperti tidak ada jangkauan jaringan, kehabisan kuota, tidak ada baterai, dsb .

\section{REMAJA GENERASI Z}

Generasi $\mathrm{Z}$ atau generasi yang sering disebut sebagai generasi yang akrab dengan teknologi (Youarti \& Hidayah, 2018). Generazi Z adalah individu yang lahir setelah 1995 sampai dengan tahun 2010 (Bakti \& Safitri, 2017; Damasdino, 2017; MUTIA, 2018) disebut juga iGeneration, Generasi Net, atau Generasi internet (Bakti \& Safitri, 2017; Mukhlis, 2015; Wibawanto, 2016). Artinya kini generasi Z berada dalam rentang usia 9 hingga 23 tahun. Santrock (dalam Pratiwi, Karini, \& Agustin, 2012) mengemukakan bahwa masa remaja adalah rentang usia 12 sampai dengan 20 tahun, yang artinya generasi $Z$ berada pada kategori usia remaja.

Generasi Z lahir dan di besarkan di era digital dimana internet telah berkembang pesat sering dengan perkembangan media elektronik dan digital (Bakti \& Safitri, 2017). Generasi Z tersebut lahir dari perpaduan dua generasi sebelumnya yaitu Generasi X dan Generasi Y (MUTIA, 2018; Shahreza, 2017). Generasi Z memiliki kesamaan dengan generasi Y, tapi generasi Z mampu mengaplikasikan semua kegiatan dalam satu waktu (multi tasking) seperti: menjalankan sosial media menggunakan ponsel, browsing menggunakan PC, dan 
mendengarkan musik menggunakan headset. Apapun yang dilakukan kebanyakan berhubungan dengan dunia maya, sehingga mereka terlalu asyik dengan perangkat ponsel atau smarphonenya.

Sejak kecil generasi $\mathrm{Z}$ ini sudah mengenal teknologi dan akrab dengan gadget canggih (Mukhlis, 2015) yang secara tidak langsung berpengaruh terhadap kepribadian (Putra, 2016). Generasi Z sudah terbiasa berkomunikasi menggunakan internet, BB, facebook, dan twitter. Mereka hidup dalam budaya yang serba cepat, sehingga tidak tahan dengan hal-hal yang lambat.

Lebih lanjut (Putra, 2016) menyatakan bagi generasi Z informasi dan teknologi adalah hal yang sudah menjadi bagian dari kehidupan mereka, karena mereka lahir dimana akses terhadap informasi, khususnya internet sudah menjadi budaya global, sehingga hal tersebut berpengaruh terhadap nilai-nilai, pandangan dan tujuan hidup mereka.

Disamping keunggulannya dalam menggunakan teknologi generasi $\mathrm{Z}$ terdapat kelemahan, misalnya mereka biasanya kurang terampil dalam komunikasi verbal (Rini, 2016). Generasi Z kurang menyukai proses, mereka pada umumnya kurang sabar dan menyukai hal-hal yang serba instan.

Berdasarkan beberapa pendapat di atas dapat disimpulkan bahwa generasi $\mathrm{Z}$ adalah mereka yang lahir setelah 1995 sampai 2010, yang artinya kini mereka berada dalam tahap perkembangan remaja. Sejak kecil remaja generasi $Z$ sudah akrab dengan kecanggihan teknologi yang menjadi bagian hidupnya sehingga berpengaruh terhadap kepribadian, nilai-nilai pandangan dan tujuan hidup mereka. Mereka juga terbiasa berkomunikasi melalui dunia maya dengan gadget akibatnya mereka kurang terampil berkomunikasi verbal. Pada remaja generasi $\mathrm{Z}$ yang sehari-hari tidak lepas dengan teknologi (ponsel atau smartphone) rentan mengalami nomophobia.

\section{ASPEK-ASPEK NOMOPHOBIA}

Yildirim(2014) menjelaskan bahwa nomophobia memiliki empat aspek, dijelaskan sebagai berikut :

\section{Perasaan tidak bisa berkomunikasi}

Aspek ini berhubungan dengan adanya kehilangan secara tiba-tiba terputus komunikasi dengan orang lain atau tidak dapat menggunakan layanan pada smartphone disaat tiba-tiba membutuhkan komunikasi.

\section{Kehilangan konektivitas}

Aspek kedua ini, berhubungan dengan perasaan kehilangan konektivitas ketika tidak dapat terhubung dengan layanan pada smartphone dan tidak dapat terhubung pada identitas sosial khususnya di media sosial.

\section{Tidak mampu mengakses informasi}

Aspek ini menggambarkan perasaan ketidaknyamanan ketika tidak dapat mengambil atau mencari informasi melalui smartphone. Hal tersebut dikarenakan, smartphone menyediakan kemudahan dalam mengakses informasi (Fajri \& Ruhaena, 2017; Hanika, 2015; Jocom, 2013). Seseorang juga merasakan dampaknya, semua informasi disebar melalui media sosial. Ketika smartphone tidak dapat digunakan maka aliran informasi yang diterima juga terganggu. Hal tersebut dapat membuat sebagian orang menjadi panik atau cemas.

\section{Menyerah pada kenyamanan}

Aspek terakhir berhubungan dengan perasaan nyaman saat menggunakan smartphone dan keinginan untuk memanfaatkan kenyamanan dalam smartphone. Ketika semua bisa dilakukan hanya dengan menatap layar ponsel, maka hal tersebut membuat hidup terasa lebih.

Selain itu menurut (Pradana, 2016) memiliki ciri-ciri dan karakteristik orang yang mengidap nomophobia yakni: (1) Menghabiskan waktu menggunakan telepon genggam, mempunyai satu atau lebih gadget dan selalu membawa charger, (2) Merasa cemas dan gugup ketika telepon genggam tidak tersedia dekat atau tidak pada tempatnya. Selain itu juga merasa tidak nyaman ketika gangguan atau tidak ada jaringan serta saat baterai lemah, (3) Selalu melihat dan mengecek layar telepon genggam untuk mencari tahu pesan atau panggilan masuk, (4) Tidak mematikan telepon genggam dan selalu sedia 24 jam, selain itu saat tidur telepon genggam diletakkan di kasur, (5) Kurang nyaman berkomunikasi secara tatap muka dan lebih memilih berkomunikasi menggunakan teknologi baru, dan (6) biaya yang dikeluarkan untuk telepon genggam besar.

Berdasarkan penjelasan di atas, dapat disimpulkan bahwa terdapat aspek-aspek nomophobia yaitu perasaan tidak bisa berkomunikasi, kehilangan konektivitas, tidak mampu mengakses informasi, menyerah pada 
kenyamanan, menghabiskan waktu menggunakan telepon genggam, mempunyai satu atau lebih gadget dan selalu membawa charger, merasa cemas dan gugup ketika telepon genggam tidak tersedia dekat atau tidak pada tempatnya, selalu melihat dan mengecek layar telepon genggam untuk mencari tahu pesan atau panggilan masuk, tidak mematikan telepon genggam dan selalu sedia 24 jam, kurang nyaman berkomunikasi secara tatap muka dan lebih memilih berkomunikasi menggunakan teknologi baru, biaya yang dikeluarkan.

\section{FAKTOR-FAKTOR YANG MEMPENGARUHI KECENDERUNGAN NOMOPHOBIA}

Menurut Bianchi \& Philip (dalam Yildirim, 2014) menyatakan faktor-faktor yang mempengaruhi nomophobia sebagai berikut:

\section{Jenis kelamin}

Secara historis tampaknya ada perbedaan jenis kelamin dalam kaitannya dengan serapan teknologi baru. Penelitian sebelumnya yang dilakukan oleh Bianchi \& Philip telah menemukan bahwa laki - laki lebih mungkin dibandingkan wanita untuk memiliki sikap positif terhadap computer.Secara logis ini menunjukkan bahwa laki laki akan lebih banyak dari perempuan yang bermasalah dalam penggunaan teknologi. Perbedaan gender adalah fungsi sosialisasi dan akses terhadap teknologi. Selain itu hasil penelitian yang dilakukan oleh Dixit, et al (2010) diketahui bahwa terdiri dari 53\% laki-laki dan $47 \%$ perempuan dimana $18,5 \%$ ditemukan bersifat nomophobia.

\section{Harga diri}

Harga diri adalah evaluasi yang relatif stabil yang membuat seseorang mempertahankan dirinya sendiri, dan cenderung menjadi penilai diri. Harga diri berkaitan dengan pandangan diri dan identitas diri(Enung, 2006). Orang-orang dengan pandangan diri buruk atau negative memiliki kecenderungan yang besar untuk mencari kepastian, telepon genggam memberikan kesempatan setiap orang untuk bisa dihubungi kapan saja dari sinilah tidak mengherankan jika orang-orang dalam mengunakan telepon genngam secara tidak tepat atau berlebihan.

Usia

Penelitian sebelumnya menunjukkan bahwa orang tua kurang memungkinkan dibanding orang muda untuk dalam pengunaan teknologi baru. Orangtua cenderung kurang dalam menggunakan teknologi baru (Mokalu, Mewengkang, \& Tangkudung, 2016) sehingga faktor usia ini mempengaruhi kecenderungan nomophobia (De Ornay, 2018; Fajri \& Ruhaena, 2017).

\section{Extraversi}

Ekstraversi umumnya suka mengambil risiko, impulsif, dan sangat membutuhkan kegembiraan(T. Lestari, 2019; T. R. P. Lestari, 2017). Ekstraversi lebih rentan terhadap masalah penggunaan telepon genggam dengan alasan bahwa mereka lebih cenderung mencari situasi sosial. Penelitian sebelumnya telah menunjukkan bahwa ekstraversi lebih rentan terhadap pengaruh teman sebaya.

\section{Neurotisme}

Neurotisme tinggi ditandai dengan kecemasan, mengkhawatirkan, kemurungan, dan sering depresi. Individu neurotisme terlalu emosional, bereaksi kuat terhadap banyak rangsangan (T. R. P. Lestari, 2017). Sedangkan Kalaskar (2015) mengemukakan faktor-faktor yang mempengaruhi terjadinya nomophobia, yaitu tingkat penggunaan, kebiasaan, dan ketergantungan yang berdampak terhadap kecemasan dalam penggunaan smartphone. Penggunaan yang berlebihan memberikan pengaruh terhadap kebiasaan dan menjadikan ketergantungan pada penggunaan smartphone.

Berdasarkan penjelasan di atas, dapat disimpulkan bahwa faktor yang mempengaruhi nomophobia adalah jenis kelamin, harga diri,usia, kepribadian, ekstraversi, neurotisme, tingkat penggunaan, kebiasaan dan ketergantungan yang berdampak terhadap kecemasan dalam penggunaan smartphone. Bahwa selain kelima faktor di atas jenis kelamin, harga diri, usia, kepribadia, ekstraversi dan neurotisme, tingkat penggunaan atau intensitas bersama smartphone menjadi faktor penting yang mempengaruhi remaja mengalami nomophobia.

\section{KESIMPULAN}

Nomophobia merupakan hasil dari perkembangan zaman, kecanggihan teknologi dan informasi di dalamnya membuat manusia banyak menciptakan hal-hal baru salah satunya mobile phone dengan fasilitasyang memudahkan aktivitas manusia atau sekarang lebih dikenal dengan istilah smartphone. Dengan segala fasilitas di dalamnya membuat penggunanya menjadi nyaman dan merasa cemas bila tidak dapat menjangkaunya. 
Remaja Generasi Z merupakan remaja yang lahir di era digital dan sejak kecil sudah mengenal teknologi dan akrab kecanggihan gadget atau smartphone. Apapun yang dilakukan kebanyakan berhubungan dengan dunia maya, sehingga mereka terlalu asyik dengan perangkat ponsel atau smarphonenya. Pada remaja generasi $\mathrm{Z}$ yang sehari-hari tidak lepas dengan teknologi khusunya pada ponsel atau smartphonenya rentan mengalami nomophobia. Banyak faktor yang menyebabkan kecenderungan mengalami nomophobia, namun upaya intensif untuk mengatasinya sepertinya tidak banyak dilakukan terutama dalam pelayanan bimbingan dan konseling.

Semoga kedepannya peningkatan, pengembangan, dan optimalisasi layanan bimbingan dan konseling untuk mengatasi nomophobia dapat terselenggara, perlunya layanan bimbingan dan konseling untuk menurunkan level nomophobia yang dialami remaja generasiZ. Remaja generasi Z dapat memperoleh bantuan untuk mengembangkan potensinya dengan kemahirannya dalam menggunakan teknologi, sehingga dapat mengembangkan potensi ke arah yang positif.

\section{REFERENSI}

Bakti, C. P., \& Safitri, N. E. (2017). Peran Bimbingan dan Konseling Untuk Menghadapi Generasi Z Dalam Perspektif Bimbingan dan Konseling Perkembangan. Jurnal Konseling GUSJIGANG, 3(1).

Damasdino, F. (2017). Dinamika akses Informasi Wisatawan Antar Generasi Pada Obyek Wisata Minat Khusus Di Kabupaten Bantul. Jurnal Media Wisata: Wahana Informasi Pariwisata, 15(1).

Dasiroh, U., Miswatun, S., Ilahi, F. Y., \& Nurjanannah. (n.d.). Fenomena Nomophobia di Kalangan Mahasiswa (Studi Deskriptif Kualitatif Mahasiswa Univeritas Rau). Jurnal Ilmiah Fakultas Ilmu Komunikasi Universitas Islam Riau, 6, 1-10.

De Ornay, B. M. M. (2018). Hubungan antara tipe kepribadian big five dengan nomophobia pada mahasiswa angkatan 2017 di Universitas Katolik Widya Mandala Surabaya. Widya Mandala Catholic University Surabaya.

Dixit, S., Shukla, H., Bhagwat, A. K., Bindal, A., Goyal, A., Zaidi, A. K., \& Shrivastava, A. (2010). A study to evaluate mobile phone dependence among students of a medical college and associated hospital of central India. Indian journal of community medicine: official publication of Indian Association of Preventive \& Social Medicine, 35(2), 339.

Enung, F. (2006). Psikologi Perkembangan (perkembangan peserta didik). Bandung: Pustaka Setia.

Fajri, F. V., \& Ruhaena, L. (2017). Hubungan Antara Penggunaan Telepon Genggam Smartphone Dengan Nomophobia Pada Mahasiswa. Universitas Muhammadiyah Surakarta.

Hafni, N. D. (2019). Nomophobhia, Penyakit Masyarakat Modern. Jurnal Al Hikmah, 6(2), 41-50.

Hanika, I. M. (2015). Fenomena phubbing di era milenia (ketergantungan seseorang pada smartphone terhadap lingkungannya). Interaksi: Jurnal Ilmu Komunikasi, 4(1), 42-51.

Hermawati. (2013). Pengolahan Citra Digital Konsep dan Teori. Yogyakarta: Andi Offset.

Jocom, N. (2013). Peran Smartphone Dalam Menunjang Kinerja Karyawan Bank Prismadana (Studi Pada Karyawan Bank Prismadana Cabang Airmadidi). Jurnal Acta Diurna, 2(1).

Kalaskar, P.B. (2015). A Study of Awareness of Development of Nomophobia Condition in Smart Phone user Management Students in Pune city. ASM's International EJournal on Ongoing Research in Management and IT, 10:320-326.

King, A. L. S., Valença, A. M., Silva, A. C., Sancassiani, F., Machado, S., \& Nardi, A. E. (2014). "Nomophobia": Impact of Cell Phone Use Interfering with Symptoms and Emotions of Individuals with Panic Disorder Compared with a Control Group. Clinical Practice \& Epidemiology in Mental Health, 10(1), 28-35. https://doi.org/10.2174/1745017901410010028

Latief, R. (n.d.). Dampak Penggunaan Smartphone dan Fenomena Nomophobia.

Lestari, T. (2019). Hubungan Antara Kepribadian Ekstraversi Dengan Nomophobia Pada Dewasa Awal. Universitas Mercu Buana Yogyakarta.

Lestari, T. R. P. (2017). Harga Diri dan Nomophobia Pada MahasiswA. Universitas Mercu Buana Yogyakarta.

Mawardi, D. H. (2018). Hubungan antara perilaku impulsif dengan kecenderungan nomophobia pada remaja. UIN Sunan Ampel Surabaya.

Mokalu, J. V, Mewengkang, N. N., \& Tangkudung, J. P. M. (2016). Dampak Teknologi Smartphone Terhadap Perilaku Orang Tua Di Desa Touure Kecamatan Tompaso. Jurnal Acta Diurna, 5(1).

Mudrikah, C. (2019). Hubungan antara sindrom FOMO (fear of missing out) dengan kecenderungan nomophobia pada remaja. UIN Sunan Ampel Surabaya.

Mukhlis, H. (2015). AF Magazine. (November), 1-34.

MUTIA, T. (2018). Generasi Milenial, Instagram dan Dramaturgi: Suatu Fenomena dalam Pengelolaan Kesan Ditinjau dari Perspektif Komunikasi Islam. An-Nida', 41(2), 240-251.

Pradana, P. W. (2016). Perancangan aplikasi liva untuk mengurangi nomophobia dengan pendekatan gamifikasi. Jurnal Teknik ITS, 5(1). 
Prasetyo, M. D. (2017). Hubungan antara Nomophobia dan Prososial pada Mahasiswa Universitas Muhammadiyah Malang. University of Muhammadiyah Malang.

Pratiwi, C. A., Karini, S. M., \& Agustin, R. W. (2012). Perbedaan tingkat post-traumatic stress disorder ditinjau dari bentuk dukungan emosi pada penyintas erupsi merapi usia remaja dan dewasa di Sleman, Yogyakarta. Wacana, 4(2).

Putra, Y. S. (2016). Theoritical Review : Teori Perbedaan Generasi. Among Makarti, 9(18), 123-134.

Rini, D. P. (2016). Pengaruh Karakter Generasi Z dan Peran Guru Dalam Pembelajaran terhadap Motivasi Belajar Akuntansi Siswa Kelas X Akuntansi SMK Negeri 1 Godean Tahun 2015/2016. UNY.

SecurEnvoy. (2012). 66\% of the population suffer from Nomophobia the fear of being without their phone. Retrieved May 13, 2019, from https://www.securenvoy.com/blog/2012/02/16/66-of-the-\%0Apopulationsuffer-from-nomophobia-the-fear-of-being-without-their- phone/\%0A

Shahreza, M. (2017). Komunikator Politik Berdasarkan Teori Generasi. Nyimak (Journal of Communication), $1(1)$.

Wibawanto, H. (2016). Generasi Z dan pembelajaran di Pendidikan Tinggi. Simposium Nasional Pendidikan Tinggi. Bandung (ID).[Internet].[Diunduh Pada Tanggal 5 Maret 2018]. Tersedia Pada: Http://Event. Elearning. Itb. Ac. Id/Assets/Download/Materi3. Pdf.

Yildirim, C. (2014). Exploring the dimensions of nomophobia: Developing and validating a questionnaire using mixed methods research.

Youarti, I. E., \& Hidayah, N. (2018). Perilaku Phubbing Sebagai Karakter Remaja Generasi Z. Jurnal Fokus Konseling, 4(1), 143-152. 